\title{
Effect of Land Use Types in Miesa Watershed on Soil Quality and Productivity
}

\author{
Fedhasa Benti $^{1^{*}}$ and Tesfaye Balemi ${ }^{2}$ \\ ${ }^{1}$ Department of Earth and Environmental Science, College of Natural and Computational Science, \\ Wollega University, P.O. Box: 395, Nekemte, Ethiopia \\ ${ }^{2}$ Department of Plant Science and Horticulture, College of Agriculture and Veterinary Science, \\ Ambo University P.O.Box: 19, Ambo, Ethiopia
}

\begin{tabular}{|c|c|}
\hline Abstract & Article Information \\
\hline $\begin{array}{l}\text { Improper land use and poor soil management practices became a great challenge to an } \\
\text { attempt to attain increase crop production to meet the growing demand for food. Areas } \\
\text { which were previously under natural forest are being converted to cropland and grazing } \\
\text { lands. The ecological effects of these changes in land use have not been thoroughly } \\
\text { investigated and documented in many parts of Ethiopia. This study was undertaken to } \\
\text { investigate the effects of land use types on physicochemical and biological properties of soil } \\
\text { and hence on soil fertility and soil productivity. In order to investigate soil fertility status, soil } \\
\text { samples collected from different land use types (cultivated land, grazing land and natural } \\
\text { forest) from the upper } 0-20 \mathrm{~cm} \text { depth were analyzed for soil quality parameters such as soil } \\
\text { pH, organic carbon, total nitrogen, available phosphorous and potassium and micro nutrients } \\
\text { (Cu, Mn, Zn and Fe) contents as well as for microbial biomass. To investigate the effect of } \\
\text { land use type on soil productivity, the study also involved growing maize crop in plastic pot } \\
\text { filled with soil samples taken from each land use type and crop performance was assessed } \\
\text { based on plant height, leaf number per plant, shoot and root weights and root to shoot ratio. } \\
\text { The results obtained showed that soil taken from natural forestland had higher value of soil } \\
\text { quality parameters such as: organic matter, total nitrogen and available phosphorus and } \\
\text { potassium contents. Other soil quality parameters such as CEC, microbial population and } \\
\text { micronutrient contents were also superior for forestland than for the other land use types. } \\
\text { Crop growth parameters such as plant height, number of leaves per plant, shoot and root } \\
\text { weights were all significantly higher for plant grown in soils taken from forestland than from } \\
\text { the other land use types. The results clearly demonstrated that the different land use types } \\
\text { had significant effects on soil quality and productivity suggesting that a change from } \\
\text { forestland to the other land use types aggravated soil degradation, thereby resulting in soil } \\
\text { fertility and productivity decline and hence in reducing crop productivity. } \\
\text { Copyright@2015 STAR Journal, Wollega University. All Rights Reserved. }\end{array}$ & $\begin{array}{l}\text { Article History: } \\
\text { Received : 06-07-2015 } \\
\text { Revised : 13-09-2015 } \\
\text { Accepted : 15-09-2015 } \\
\text { Keywords: } \\
\text { Land use types } \\
\text { Soil management practices } \\
\text { Crop production } \\
\text { Soil fertility } \\
\text { Soil productivity } \\
\text { Miesa Watershed } \\
\text { *Corresponding Author: } \\
\text { Fedhasa Benti } \\
\text { E-mail: } \\
\text { fedeesa@gmail.com }\end{array}$ \\
\hline
\end{tabular}

\section{INTRODUCTION}

Improper land use is being observed as a result of the challenges to increase food production to meet the food demand of increased population potentially resulting in land degradation. Land degradation in turn has severe negative impact on agronomic productivity of crops, environmental quality and on food security and overall livelihood of human beings (Omotayo and Chukwuka, 2009). Traditional farming practices such as slash and burn, removal/burning of crop residues, overgrazing, and continuous cultivation without fallowing and excessive plowing tremendously aggravated soil degradation through resulting in decline of soil fertility and organic matter and soil acidification (Omotayo and Chukwuka, 2009). National crop yield averages in tropical Africa rarely show an upward trend despite availability of improved cultivars and agrochemical inputs mainly because of such severe soil-related constraints (Lal, 1987).
Increased human population exerted high pressure on existing cropland as well as grazing land resources further demanding encroachment of forest areas for food production (Mudimu, 1998; Coppock, 1989). The expansions of agricultural land in the tropical forest areas for instance have been responsible for at least $50 \%$ of deforestation since 1970s (Myers, 1991). From 1970 to 1999 , lands under arable and permanent crops increased by 1.9 million hectares (Mha) while the areas under forests decreased by 3.1 (Mha) over the same time (FAO, 1999). The major reason behind opting for horizontal expansion as a means to increase food production has been the inability of farmers to adopt improved farming practices for intensification of agricultural production. As a result, soil degradation remained a serious problem in most developing countries due to the mining of soil fertility and a serious problem of soil erosion following the periodic change in land use (Zhang et al., 2011). 
Fedhasa Benti and Tesfaye Balemi

A decline in crop yields is a major concern, especially in sub-Saharan Africa, where the lack of achievement of food security is closely linked with land degradation due to nutrient mining. A decline in soil fertility as a result of land degradation has resulted in a decline in farmland productivity (Amede, 2003). Miessa Micro watershed is very much associated with severely lower crop productivity due to soil degradation. Land resource management in the area were not based on scientific recommendations but were based entirely on traditional experiences, which has further aggravated the problem of soil degradation in the area. Although there is a general understanding that soils of the area are being degraded, the extent and magnitude of the degradation is, however not known. This necessitated an investigation of the extent of soil degradation in terms of soil fertility and productivity under different land use systems. A decline in soil productivity induced by change in land use system was observed in many parts of the world (Mulumba, 2004; Ayoubi et al., 2011; Aghasi et al., 2011). Such decline in soil productivity was mainly attributed to loss of soil fertility as a result of conversion, mainly of forestland to cropland, which is highly prone to severe soil erosion and organic matter loss.

Due to the absence of detailed information on the extent of land degradation under different land use systems in Ethiopia, sound soil reclamation practices and land use decisions by policy makers could not be established. Thus, there is a need to investigate the difference in the extent of soil degradation, measured in terms of various soil quality parameters, under different land use types in order to fill the knowledge gaps. It is assumed that awareness creation on the extent of land degradation among the farmers, policy makers and other stake holders would help easy adoption of the recommendation and any decisions made by the policy makers to safeguard soil from further degradation. Thus, there is a need to investigate the relationship between land use types and soil quality and productivity to further influence farmers in their decision to choose appropriate land resource management strategy in Miessa Watershed. The objectives of the present study were, therefore, to investigate the effects of different land use types on soil quality based on soil quality parameters (physical, chemical and biological) and to identify the effects of different land use types on soil productivity through crops performance evaluation approach.

\section{MATERIALS AND METHODS}

\section{Characterization of the Study Area}

The study was carried out at Miessa Micro watershed. It is located in West Shewa zone of Oromia Regional State, Ethiopia. It is situated between longitude $8047^{\prime} \mathrm{N}$ $9021^{\prime} \mathrm{N}$ and latitude 37032 ' E - 380 3' E .The altitude of the area ranges between 1500 and $3100 \mathrm{~m}$. a.s.l. The average annual rainfall is $970 \mathrm{~mm}$ per year. The area is characterized by bimodal rainfall distribution with small amount of rainfall during autumn season and long rainfall during summer season. Heavy rain is observed from the onset of July to the end of August. The annual temperature ranges between $10^{\circ} \mathrm{C}$ to $26^{\circ} \mathrm{C}$ with an average temperature of $18^{\circ} \mathrm{C}$. The farming system of the study is predominantly rain fed. The livelihood of the people is exclusively based on agriculture. The agricultural activities carried out in the area include mixed farming system where there is an integration of crop cultivation and animal husbandry. The soil of the study
Sci. Technol. Arts Res. J., July-Sep 2015, 4(3): 83-92

area was classified into three main types when classified based on their colors: black soils, brown soils and red soils and the soil is highly dominated by clay minerals (AWADO, 2010).

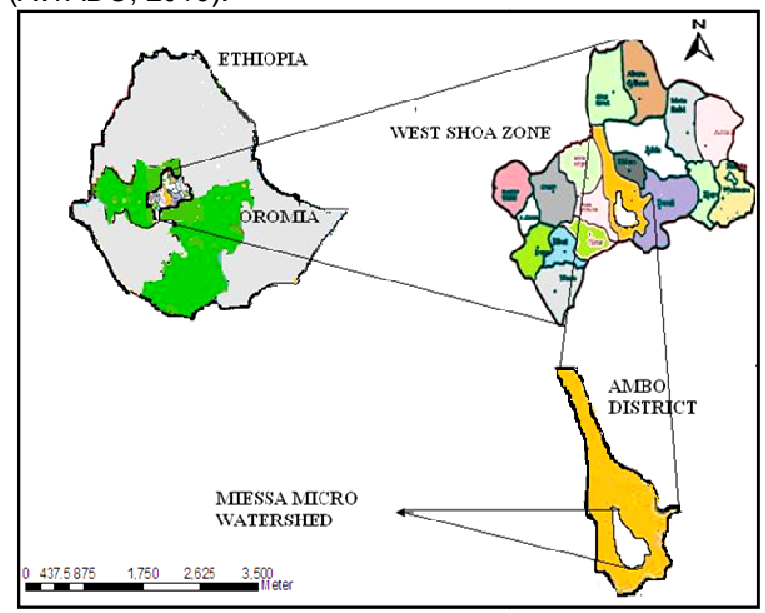

Figure 1: Study area

\section{Soil Sample Collection}

Soil samples were collected from the top soil (depth of 0-20 cm) using Auger, where most changes in soil quality were expected to occur for the different land uses. The bulk of the soil samples collected from each land use type were separately air dried and passed through $2 \mathrm{~mm}$ sieve after which they were thoroughly homogenized before analyzed. Soil samples for samples of organic matter determination were sieved through $5 \mathrm{~mm}$ sieve size.

\section{Determination of Soil Quality Parameter}

Soil pH: was determined at a 1:2.5 soil-water ratio using standard pH meter (Jackson, 1973).

Bulk Density (BD): Bulk density was determined from the soil core using the procedure given by Veihmeyer and Hendrickson (1948).

Cation Exchange Capacity (CEC): Cation exchange capacity (CEC) was measured by the sodium saturation method (Jackson, 1973).

Soil Organic Carbon (SOC): Soil organic carbon was determined by wet digestion method according to Walkley and Black (1934).

Percent organic carbon was calculated using the following equation:

$$
O C \%=\frac{N(V 1-V 2)}{S} 0.39 m c f
$$

Where, $\mathrm{N}$ is the normality of ferrous sulfate solution (from blank titration), V1 and V2 are the volumes ( $\mathrm{ml}$ ) of ferrous sulfate solution for the blank and for the soil sample, respectively, $S$ is the weight of air-dried soil sample (g), and mcf is a moisture correction factor.

Organic Matter Content (OM): Organic matter content was derived from percent organic carbon computed as:

$$
\mathrm{OM} \%=\mathrm{C} \% \times 1.724
$$

Total Nitrogen (TN): Total nitrogen was determined by the Kjeldahl method (Bremner and Mulvaney, 1982).

Available Phosphorous (AP): Available phosphorus in soil sample was determined by extracting the samples 
Fedhasa Benti and Tesfaye Balemi

with $0.5 \mathrm{M} \mathrm{NaHCO}$, and determining $P$ colorimetrical using ammonium molybdate (Olsen et al., 1954).

Available Potassium (AK): Available potassium was determined by using flame photometer.

Micronutrients: Available Iron, Copper, Zinc and Manganese were determined by using atomic absorption spectrometer (Lindsay and Norvell, 1978). The method consists of shaking with a buffered solution which extracts easily soluble $\mathrm{Cu}, \mathrm{Zn}, \mathrm{Fe}$, and $\mathrm{Mn}$.

Soil Microbial Count: The load of microorganisms in soil taken from the different land use types was determined by repeatedly diluting the amount of microorganisms in samples and then numbers of microorganisms were estimated by using the following formula.

$$
\mathrm{B}=\frac{\mathrm{NCFU}}{\mathrm{VXTD}} \rightarrow \frac{\mathrm{NCFU}}{\mathrm{gm}}
$$

Where NCFU $=$ Number of colony factor unit; $\mathrm{V}=$ Volume $(\mathrm{ml})$ of Plate and TD $=$ Total dilution $\left(1: 10^{3}\right)$

Soil Degradation Index (DI) was computed by the procedure of Adejuwon and Ekanade (1988) and Islam and Wail (2000). To compute DI, the difference between mean values of each soil quality parameter under cultivated and grazing lands, and the baseline values of similar soil quality parameter for forestland were computed and expressed as a percentage of the value under the forestland. These percentage changes were summed across all soil quality parameters to compute the cumulative DI value for each land use types, which was used as an overall index of soil degradation or improvement.

$$
\text { DI }=\frac{(A-B) \times 100)}{B}
$$

Where $D I=$ degradation Index; $A=$ the mean value of soil quality parameter for cultivated land or grazing land and $B=$ the mean value of soil quality parameter for soil from forestland

\section{Soil Productivity Assessment}

Productivity of the soils from the three different land use types were compared by evaluating crop performances based on plant growth parameters. The experiment involved growing maize crop for 30 days in plastic pots ( 5 Lit) filled with soil samples taken at a depth of $0-20 \mathrm{~cm}$ from the different land use types. The plastic pots filled with soil samples from each land use type were arranged in Randomized Complete Block Design (RCBD) with four replications. Seeds of hybrid maize (Jibat) having equal size were selected and sown. The plants were grown in the glass house at Ambo University. Then the plants were harvested after 30 days of sowing. Plant parameters such as days to emergence, shoot fresh and dry weights and root fresh and dry weights, leaf numbers per plants, leaf length, plant height and root to shoot ratio. The data recorded was used to assess the relative productivity of the soils from the different land use types.

\section{Data Analysis}

The quantitative data generated from soil laboratory test and plant growth parameters for the pot experiment were analyzed using PROC GLM procedure of SAS institute INC., Cary, USA). Treatment means were compared according to Tukey test and for all analysis a significance level at $\alpha=0.05$ was used.
Sci. Technol. Arts Res. J., July-Sep 2015, 4(3): 83-92

\section{RESULTS AND DISCUSSION}

Effect of Land Use Type on Soil pH, Bulk Density and CEC

Soil $\mathrm{pH}$ was significantly influenced by soil taken from different land use types $(p<0.01)$. Results revealed that soil $\mathrm{pH}$ varied from 6.8 to 7.5 for the different land use type (Table 1).

Table 1: Effect of land use types on soil pH, BD and CEC

\begin{tabular}{lccc}
\hline Land use types & Soil $\mathbf{p H}$ & $\begin{array}{c}\mathbf{B D} \\
(\mathbf{g ~ c m}\end{array}$ & $\begin{array}{c}\mathbf{C E C} \\
(\mathbf{m e q} / \mathbf{1 0 0} \mathbf{g})\end{array}$ \\
\hline Cultivated land & $6.8^{\mathrm{b}}$ & $1.12^{\mathrm{a}}$ & $81.8^{\mathrm{b}}$ \\
Grazing land & $7.3^{\mathrm{a}}$ & $0.98^{\mathrm{b}}$ & $77.5^{\mathrm{c}}$ \\
Forest land & $7.5^{\mathrm{a}}$ & $0.91^{\mathrm{c}}$ & $85.6^{\mathrm{a}}$
\end{tabular}

(Data in the same column followed by the same letter are not significantly different from each other at probability level of $\alpha=$ 0.05 according to Tukey test)

Soil obtained from the forest and grazing lands showed significantly higher soil $\mathrm{pH}$ values as compared to that of the cultivated land. But $\mathrm{pH}$ value from the two land use types (forest and grazing lands) were at par. The lower $\mathrm{pH}$ value of soil from the cultivated land might be related to the application of fertilizers containing ammonium/ urea, which tended to reduce the $\mathrm{pH}$ since ammonium uptake is accompanied by release of hydrogen ion to the soil. (Mendel and Kirkby, 2001). Other reason could also be that the higher organic matter decomposition rate in cultivated land due to aeration might have resulted in release of organic acids which ultimately contributed to the acidic tendency of the soil. I agreement with our observation, Aghasi et al. (2011) also reported lower soil $\mathrm{pH}$ value for cultivated/farmland than for grass/grazing land. However, a contrary result have been observed by Steenwerth et al. (2002) and Mulumba (2004) who observed lower soil pH for grazing land compared to cultivated land.

Soil Bulk density (BD) was also significantly influenced by the different land use types $(p<0.001)$. The bulk density $\left(\mathrm{g} / \mathrm{cm}^{3}\right)$ obtained from the three land use types were 1.11 , 0.98 and 0.92 for cultivated, grazing, and forest lands, respectively (Table 1). Results showed that the BD of soil taken from cultivated land was significantly higher as compared to the BD of soils of taken from both grazing and forest lands. In agreement with the present finding, Islam and Weil (2000) also reported higher BD for soil from cultivated land, medium BD for soil from grazing land and lower BD for soil taken from natural forest. The higher bulk density observed in soils taken from cultivated land could be ascribed to lower OM content as a result of continuous cropping without fallowing and poor crop residue management since according to Arshad et al. (1996) practices such continuous tillage/cropping and removal or burning of crop residues increased soil bulk density. The lowest bulk density observed for soil obtained from forest land on the other hand might be related to its high soil OM content (Figure 1A) as compared to soils from cultivated and grazing lands. Organic matter reduces bulk density since OM is much lighter in weight than a corresponding volume of mineral matter and also since OM gives increased aggregate stability to a soil (Troeh and Thompson, 1993) so that soil with higher OM content has less degree of compaction than soil with less OM content. 
Fedhasa Benti and Tesfaye Balemi

The Cation exchangeable capacity (CEC) of soil taken from different land use types was significantly affected by the land use types $(p<0.001)$. The CEC $(\mathrm{Meq} / 100 \mathrm{gm})$ in soil of the three land use types were $81.55,77.5$ and 85.6 for cultivated, grazing and forest land, respectively (Table 1). The CEC of soil from forestland was significantly higher as compared to the CEC of soil taken from grazing and cultivated lands whereas the CEC in soil of cultivated land was in turn higher than that of the grazing land. This result however, contradicts with the result reported by Aghasi et al. (2011) who observed higher CEC for grazing land than for cultivated land. Based on FAO (2006), the CEC observed in the current study for the soil obtained from forest and cultivated lands were considered as very high whereas that of the grazing land was considered as high. The higher CEC values in soil from forest and cultivated lands can be attributed to the higher $\mathrm{OM}$ content in the former and higher clay percentage in the later since soil with high OM and clay has more exchange sites and high CEC (Sachs, 1999). Soil CEC is associated with clay and organic matter colloids, and according to Wild (1993) organic matter render soils a better CEC. According to Charman and Murphy (2000) CEC is highly determined by the level of OM and soil texture and a decline in soil OM substantially decreased the CEC (Donovan and Casey, 1998). This finding is in agreement with the results of Wolde and Edzo (2005) who also observed a significantly higher CEC in closed areas than in free grazing lands. Moreover, our result is also in agreement with the results of Lumbanraja et al. (1998) who observed a significant decreasing trend in CEC when a virgin land under natural vegetation is changed to a farmland that was continuously cultivated for years. Furthermore, the results of this study also support the work of Ayele (2005) who reported that the CEC values of the soil under cultivation were lower than that of forestland by more than $50 \%$. The reason for such decline in CEC with land use change from forestland to farm land might be attributed to the decline in soil OM content through erosion and nutrient cycling/decomposition.

\section{Effect of Land Use Types on Soil Organic Matter, Soil Total Nitrogen, Available Phosphorus and Potassium Contents}

Soil organic matter (SOM) content was significantly influenced by the different land use types $(p<0.001)$. The SOM (\%) was 5.2, 5.5 and 8.9 for soil taken from cultivated, grazing and forest land, respectively (Figure 2A). Results showed that OM in soil from forestland was significantly higher as compared to the OM content of soil taken from both cultivated and grazing lands. OM content in soil of grazing land and cultivated land, in contrast, was at par. Previous studies showed that total soil carbon content, the principal component of $\mathrm{OM}$, in forest ecosystem was greater than both the grassland ecosystem and agro ecosystem whereas in turn grazing land ecosystem was greater than agro ecosystems (Eshetu, 2010). According to soil organic carbon content rating by Lal (1994), the soil organic carbon content observed in this study for forest soil was classified as high whereas for both cultivated and grazing lands was rated as low (Data not presented). Several studies showed that soil OM content was reduced by intensive cultivation of land (Rutberg,et al., 1996). Ayanaba et al. (1976) reported that the SOC concentration rapidly declined after forest clearing and when maize crop residues were removed from the site supporting the present finding. Collins et al. (1999) also observed that SOC concentration declined in
Sci. Technol. Arts Res. J., July-Sep 2015, 4(3): 83-92

cultivated soils as compared to adjacent non-cultivated sites. The reason behind the higher OM content in soil taken from forestland was probably related to addition of OM inputs by forest trees since forest trees drop leaves and root debris which when partially decomposed enhance $\mathrm{OM}$ content. The higher litter production and $\mathrm{N}$ fixation by nitrogen fixing trees species (leguminous trees) and higher microbial population in forestland facilitates partial decomposition of soil OM inputs of thereby resulting in higher OM content of such soil.

The lower level of OM content in soils obtained from cultivated land might resulted from a combined effect of lower OM inputs addition into the soil system (less biomass due to poor crop residue management) and greater OM input losses through crop residue burning/removal, accelerated top soil erosion and faster organic matter decomposition due to the high soil aeration. In line with the present findings, Robert (2001) reported that forests contribute 40 to $60 \%$ of the OM to the soil as compared to other land use types. The lower OM content in grazing and cultivated lands of the study area could be attributed to heavy livestock traffic and poor agricultural practices such as poor crop residue managements, respectively. In line with our finding, Lal (1986) reported that crop management practices and cropping systems that don't return crop residues to the soil led to severe decline in SOC content. Similarly, increased aeration due to tillage enhances mineralization thus resulting in a decline in SOM content (Rutberg et al., 1996).

Likewise, total nitrogen (TN) of the soil was significantly influenced by the land use types $(p<0.001)$. The TN (\%) was $0.12,0.19$, and 0.5 for soil from cultivated, grazing and forest lands, respectively (Figure $2 \mathrm{~B}$ ). Data presented in Figure $2 \mathrm{~B}$ revealed that the total nitrogen (TN) content of soils obtained from forestland was significantly higher than the TN content in soil taken from both cultivated and grazing lands. The TN content in soil from grazing land was in turn significantly higher than the TN in soil from cultivated land. Based on the TN content rating by Barber (1984) the TN content of soil from forestland fall in the "very high" class whereas that of the cultivated and grazing lands fall in the "low" class (Table 1). The higher TN content in soil from forestland might be due to the fact that the forest ecosystem was dominated by nitrogen fixing trees (vegetation data not shown) which might have resulted in biological nitrogen fixation. Moreover, the high litters in the forest ecosystem might have led to mineralization of organic nitrogen, which in turn has enhanced the soil TN content. The low level of TN in cultivated land in contrast, could be attributed to the reduction in SOM content, unchecked soil erosion, nutrient removal along with crop residues at harvest, removal of the nitrogen fixing trees, continuous cropping without fallowing, lack/suboptimal application of inorganic $\mathrm{N}$ fertilizers and absence of manure application (socioeconomic data not shown). On the other hand, the lower TN content of soil taken from grazing land could be due to the adverse effects of overstocking of livestock, which might have caused soil degradation. In support of our finding, Wolde and Veldkamp (2005) also observed higher TN content in closed areas as compared to free grazing lands.

Available phosphorus (AP) content of the soil was significantly affected by different land use types 


\section{Fedhasa Benti and Tesfaye Balemi}

$(p<0.001)$. The AP content of soil from the three land use types were $3.12,4.21$ and 7.15 ppm for cultivated, grazing and forest lands, respectively (Figure 2C). Results showed that AP content of soil from forestland was significantly higher as compared to the AP content of soil from cultivated and grazing lands. Based on soil AP content rating by Barber (1984), the AP in soils of each land us type was generally low. However, the AP content was relatively significantly lower in soil from cultivated land than that of the forest and grazing lands. Plant uptake, erosion, leaching and fixation are probably accountable for losses of phosphorous from the soil system. The higher AP content of forest soil might be attributed to the higher quantity of litter fall to forest soil as compared to soil of both cultivated and grazing lands since Silver (1994) found a high correlation between litter fall and soil AP content. However, the AP content in the soil the forestland was still lower than the optimum AP
Sci. Technol. Arts Res. J., July-Sep 2015, 4(3): 83-92

required for optimum plant growth. Contrary to our present finding, Aghasi et al. (2011) did not observe any significant effect of land use change on the soil AP.

Similarly, available potassium (AK) from different soil types was significantly influenced by the land use types $(p<0.001)$. AK in soil obtained from forest and grazing lands was significantly higher than in soils from cultivated land whereas, AK content of soils from forest and grazing land was at par (Figure 2D). Even though the soils in Ethiopia are believed to be rich in potassium, the value of available potassium, in this study, for cultivated land was quite low perhaps due to continuous uptake by the plant without being replenished through fertilizer application. In agreement with this finding, Eshetu (2010) also reported that the AK in soil taken from forest land was significantly higher than that of both free grazing and cultivated lands.
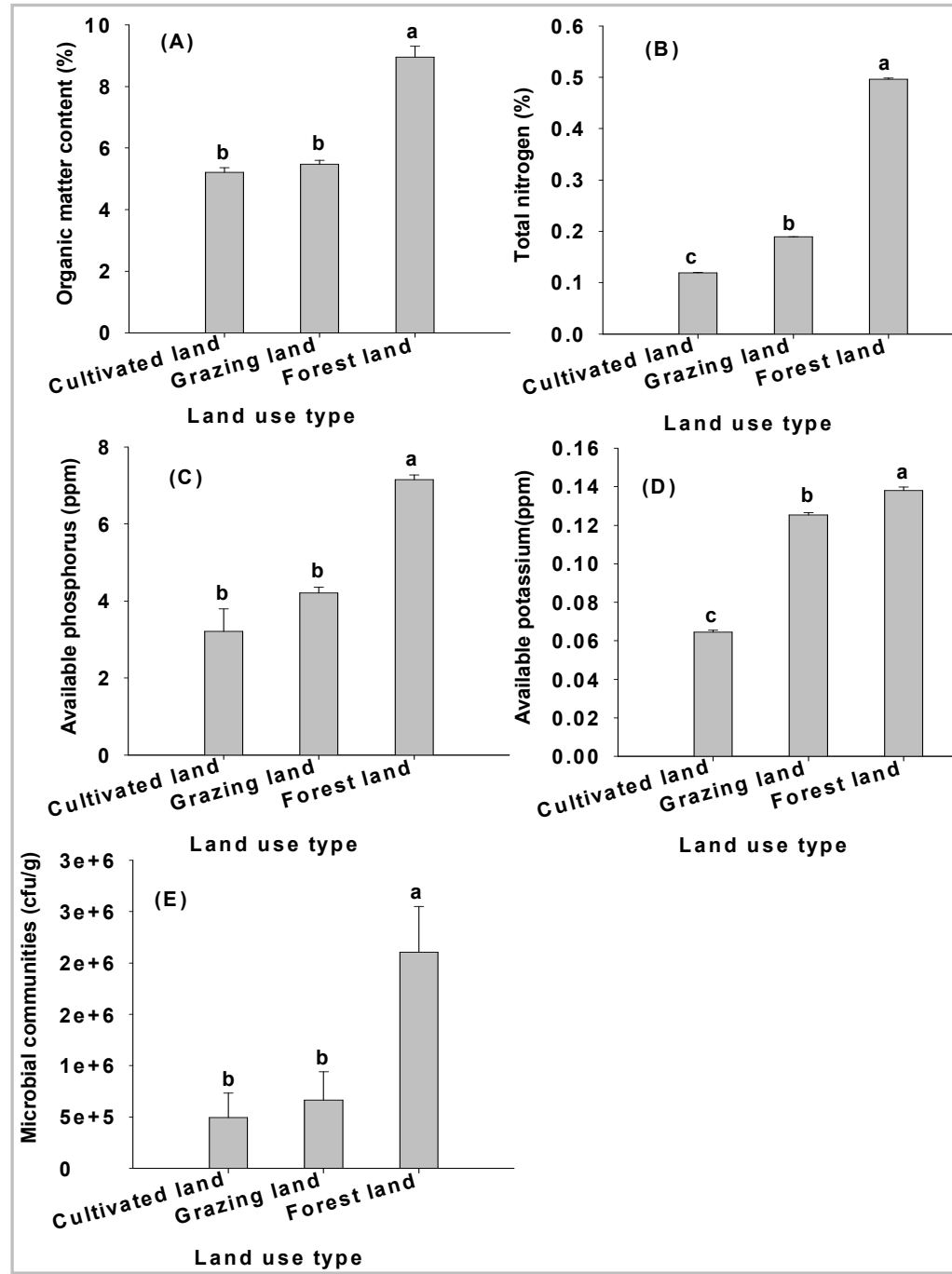

Figure 2: Organic matter (A) total nitrogen (B) available phosphorus (C) and potassium (D) and microbial population (E) contents as affected by land use types (Bars followed by the same letter are not significantly different from each other at probability level of $\alpha=0.05$ according to Tukey test).

\section{Effect of Land Use Type on Soil Microbial Count}

Soil microbial community was significantly influenced by the different land use types $(p<0.05)$. The microbial community (cfu/g) was recorded as $4.95 \times 10^{5}, 6.64 \times 10^{5}$ and $2.105 \times 10^{6}$ for cultivated, grazing and cultivated lands, respectively (Figure 2E). Data showed that microbial communities in soil of forestland were significantly higher as compared to that of cultivated and grazing lands whereas, microbial communities in soil taken from cultivated and grazing lands were at par. In agreement to 
Fedhasa Benti and Tesfaye Balemi

our finding, Nyle (2002) reported that soils of forest lands support greater numbers of microorganism than do grazing lands whereas, microbial communities in soil of cultivated fields were generally lower than undisturbed native soils in terms of numbers and biomass. The lower microbial community in soil from cultivated and grazing lands might be related to the adverse effects of agricultural practices such as change in soil $\mathrm{pH}$ as a result of chemical fertilizer application, application of pesticides and fungicides and overgrazing that in one way or another reduce diversity as well as the total population of microorganism in the soil since reports of Nyle (2002) indicated that the application of pesticides, especially soil fumigants reduced microbial communities. Moreover, soil erosion and excess tillage sharply reduced soil microbial communities through their influence on soil OM content Nyle (2002).

\section{Effect of Land Use Type on Soil Micro Nutrient Content}

The copper $(\mathrm{Cu})$ content of the soil was significantly affected by the land use types $(p<0.001)$. The concentration of $\mathrm{Cu}(\mathrm{ppm})$ in soils from the three-land use types were 49, 49 and 78 for cultivated, grazing and forestlands, respectively (Table 2). Data obtained from soil analysis showed that the concentration of $\mathrm{Cu}$ in soil taken from forestland was significantly higher as compared to that of both grazing and cultivated lands. On the other hand, the $\mathrm{Cu}$ content of soil from both cultivated and grazing lands was at par (Table 2). The higher $\mathrm{Cu}$ concentration in forest soil was attributed to the presence of higher OM in forest soil since cupper had the highest affinity to OM. Similarly, Schnitzer and Skinner (1967) recorded higher proportion of $\mathrm{Cu}$ bound to $\mathrm{OM}$ since the divalent $\mathrm{Cu}$ ion has the strongest affinity to soil $\mathrm{OM}$ as compared to any other divalent cations. Recent finding indicated that a large proportion of $\mathrm{Cu}^{+2}$ are also bound covalently to carboxylic groups that occur in humic and fulvic acids in soil OM (Schnitzer and Skinner, 1967).

The zinc ( $\mathrm{Zn})$ content of the soil was also significantly influenced by the different land use types $(p<0.001)$. Available Zinc (ppm) in the soils from the three land use types were 67, 124 and 75 for cultivated, grazing and forest lands, respectively, Results obtained revealed that
Sci. Technol. Arts Res. J., July-Sep 2015, 4(3): 83-92

the concentration of $\mathrm{Zn}$ in soil from grazing land was significantly higher as compared to the concentration of $\mathrm{Zn}$ in soil from both forest and cultivated lands. The $\mathrm{Zn}$ content of forest soil was in turn significantly higher as compared to that of cultivated land (Table 2). The lower availability $\mathrm{Zn}$ in soil from cultivated land might be related to the lower microbial population (Figure 2E) of the soil since the presence of the microorganisms releasing phytosidrophores normal play significant role in $\mathrm{Zn}$ mobilization and its availability in the soil.

Similarly, the manganese $(\mathrm{Mn})$ content of the soil was also significantly affected by different land use types $(p<0.001)$. The available $\mathrm{Mn}$ content was significantly higher in soil from forestland than from both grazing and forest lands (Table 2). The higher Mn content in soil of forestland might be due to anaerobic microbial respiration which leads to a reduction of $\mathrm{Mn}^{+4}$ (unavailable from) to $\mathrm{Mn}^{+2}$ (available form). Pual and Clark (1996) reported that under the anaerobic conditions $\mathrm{Mn}^{+4}$ is reduced to $\mathrm{Mn}^{2+}$ by manganese reducing microorganisms for respiratory functions. In addition to soil microbial respiration, the higher available $\mathrm{Mn}$ in soil from forest land compared to the other land use types might be due to the higher OM content of the soil since according to Cotter and Mishra (1968) soil which is rich in OM have higher concentration of available $\mathrm{Mn}$. On the other hand, the lower available Mn content of soil from cultivated land might be due to loss of Mn through soil erosion and uptake by crop plant, which is ultimately removed through grain yields and crop residues.

The Iron (Fe) content of the soil was also significantly affected by the different land use types $(p<0.001)$. The concentration of iron (ppm) in the soils of the three land use types were 564, 463 and 677.7 for cultivated, grazing and forest lands, respectively. Results showed that $\mathrm{Fe}$ content in soil of forestland was significantly higher as compared to both cultivated and grazing lands. The relatively higher Fe content of forest land (Table 2) might be attributed to the release of photosiderophores by microorganisms which enhance $\mathrm{Fe}$ availability through chelating effects (Barton and Abadia, 2007).

Table 2: Effect of land use type on soil micronutrient content of the soil as affected by different land use types

\begin{tabular}{lccc}
\hline \multicolumn{1}{c}{ Variables } & Cultivated Land & Grazing Land & Forest Land \\
\hline Copper (ppm) & $49^{\mathrm{b}}$ & $49^{\mathrm{b}}$ & $78^{\mathrm{a}}$ \\
Zinc (ppm) & $67^{\mathrm{c}}$ & $124^{\mathrm{a}}$ & $75^{\mathrm{b}}$ \\
Manganese (ppm) & $79^{\mathrm{c}}$ & $118^{\mathrm{b}}$ & $183^{\mathrm{a}}$ \\
Iron (ppm) & $564^{\mathrm{b}}$ & $463^{\mathrm{c}}$ & $677.5^{\mathrm{a}}$ \\
\hline \multicolumn{2}{c}{ (Data in the same row followed by the same letter are not significantly different } \\
from each other at Probability level of $\alpha=0.05$ according to Tukey test)
\end{tabular}

\section{Soil Degradation Index}

A perusal of data presented on figure 3 showed that total nitrogen was the highly deteriorated soil parameter with values of $-76.2(\%)$, and $-62.2(\%)$ for cultivated and grazing lands, respectively. This could possibly be due to higher mineralization followed by plant uptake and loss through soil erosion especially on cultivated land. Available phosphorus was the second most deteriorated soil parameters with value of $-56.36(\%)$ and $-41.12(\%)$ for cultivated and grazing lands, respectively. Available potassium was the third most degraded soil parameters with the values of $-53.97(\%)$ and $-9.2(\%)$ for cultivated and grazing lands, respectively. Organic matter content was the fourth most affected soil parameter with values of
$-41.68(\%)$ and $-38.88(\%)$ for cultivated and grazing lands, respectively. Bulk density was the fifth most deteriorated soil parameter with values of $-20.11(\%)$ and $6.74(\%)$ for cultivated and grazing lands, respectively. The relatively higher degradation index of BD in cultivated land $(-20.11 \%)$ compared to that of grazing land $(-6.74 \%)$ might be due to the highly reduced OM content of cultivated land compared to that of grazing land. The cation exchange capacity of soil from grazing land deteriorated more severely than that of cultivated land with value- 15.77 and $-4.73(\%)$ for grazing and cultivated lands, respectively. 


\section{Fedhasa Benti and Tesfaye Balemi}

Soil $\mathrm{pH}$ was the least deteriorated soil parameter according to this study with degradation index (DI) values of $-9.67(\%)$ and -2.67 for cultivated and grazing lands, respectively. Generally, the soil from cultivated land was the most deteriorated land use type in terms of cumulative DI value of soil quality parameters with a total degradation index value of -261.7 (\%) followed by grazing land with the value of $176.6(\%)$ when soil quality parameters value of forest land is used as a baseline. Comparison of the
Sci. Technol. Arts Res. J., July-Sep 2015, 4(3): 83-92

degradation index of cultivated and grazing lands reports of Eshetu (2010) with the present result showed that the $\mathrm{DI}$ of the present study was better by $+14.2(\%)$ for cultivated land and worst by $-5.78(\%)$ for grazing land. The negative cumulative degradation index (DI) of the cultivated and grazing land indicates that the overall soil condition of the two land use types were inferior to that of the natural forest.
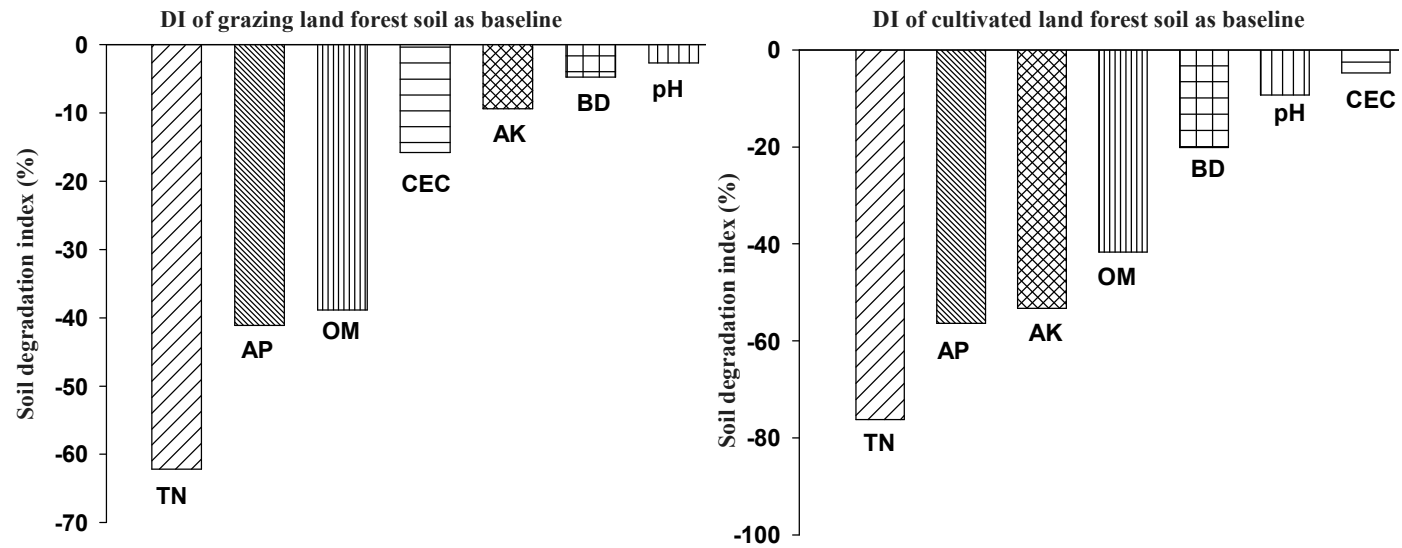

Figure 3: Degradation index of different soil quality parameters for grazing land (left) and cultivated land (right)

\section{Effect of Different Land Use Types on Plant Growth} Parameters

Days to emergence was significantly influenced by soils taken from different land use types $(p<0.001)$. Days required for emergence of maize seed sown on different land uses were $6.5,5.5$ and 5 days for cultivated, grazing and forest lands, respectively. Results showed that maize seeds sown in soil from forest land emerged early as compared to maize seeds sown in soils of both grazing and cultivated lands whereas maize seeds sown in soil from cultivated land emerged late as compared to the seeds sown in soil from both grazing and forest lands. The difference in emergence might be associated with deference in the so called "started nutrient" contents such as phosphorus. Another reason could be that soil from cultivated land being compact (higher bulk density) was oxygen deficient since oxygen is one of the limiting factors for seed germination.

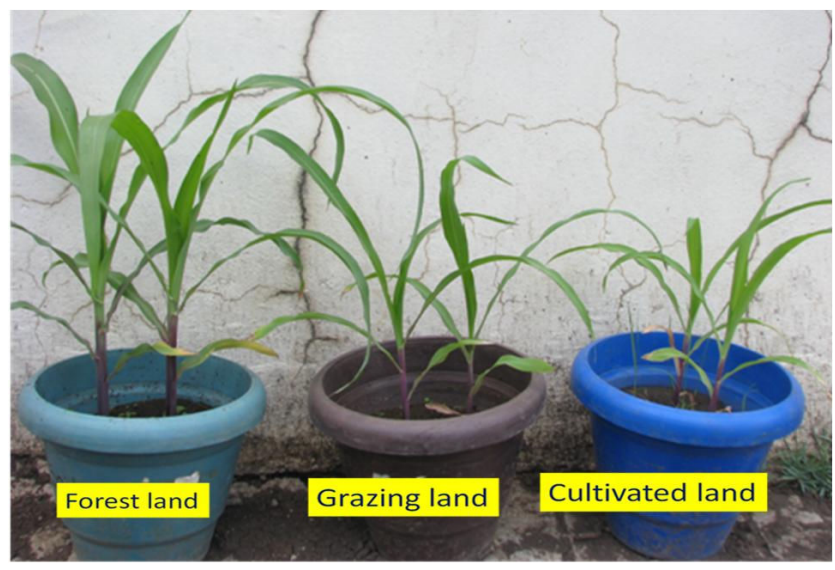

Figure 4: Picture of maize plant grown in soils obtained from different land use types

Leaf length was highly influenced by the land use types $(p<0.001)$. The leaf length $(\mathrm{cm})$ for plants grown in soil taken from the three land use types were 36,36 and 59.75 for cultivated, grazing and forest lands, respectively. Results showed that leaf length of plant grown in soil taken from forest land was significantly higher as compared to the leaf length of plant grown in both cultivated and grazing land. But leaf length of plant grown in soils taken from both grazing and cultivated land was at par. The shorter leaf length of maize plant grown in soil of cultivated land might be related to deficiency of plant nutrients that inhibit leaf growth. Plants suffering from phosphorus and nitrogen deficiency normally exhibit inhibited leaf growth. Fredeen et al. (1989) reported that phosphorus deficiency resulted in restricted delivery of water to leaves due to poor root hydraulic conductance which in turn limited leaf growth supporting the present results.

Similarly, plant height was also significantly affected by the different land use types $(P<0.001)$. The height $(\mathrm{cm})$ of plant grown in the soils obtained from the three land use types were $15.25,16$ and 27.75 for cultivated, grazing and 


\section{Fedhasa Benti and Tesfaye Balemi}

forest lands, respectively. Results showed that the height of maize plant grown in soil taken from forestland was significantly higher as compared to the height of plant grown in soils of both cultivated and grazing lands (Figure $5 \mathrm{C})$. The number of leaves per plant for plants grown on soils of both grazing and cultivated lands was also significantly lower than the leaf number of maize plant
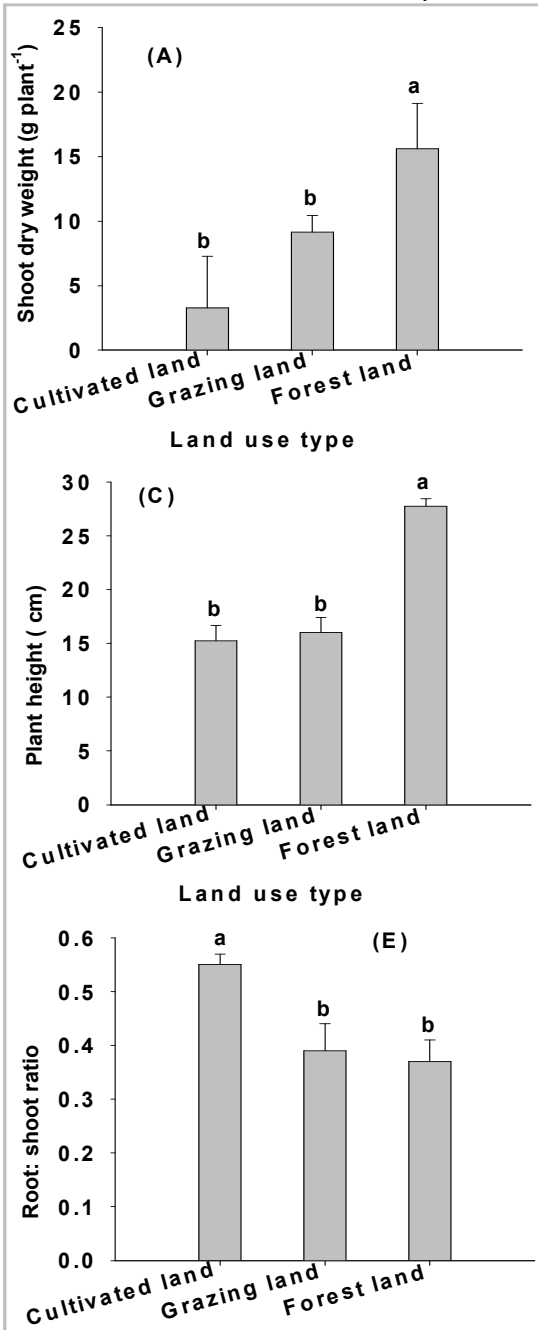

Land use type
Sci. Technol. Arts Res. J., July-Sep 2015, 4(3): 83-92

grown on soil from forestland (data not shown). On the other hand, the number of leaves as well as plant height of maize plant grown on both soil of grazing and cultivated lands were not significantly different from each other (Figure 5C).
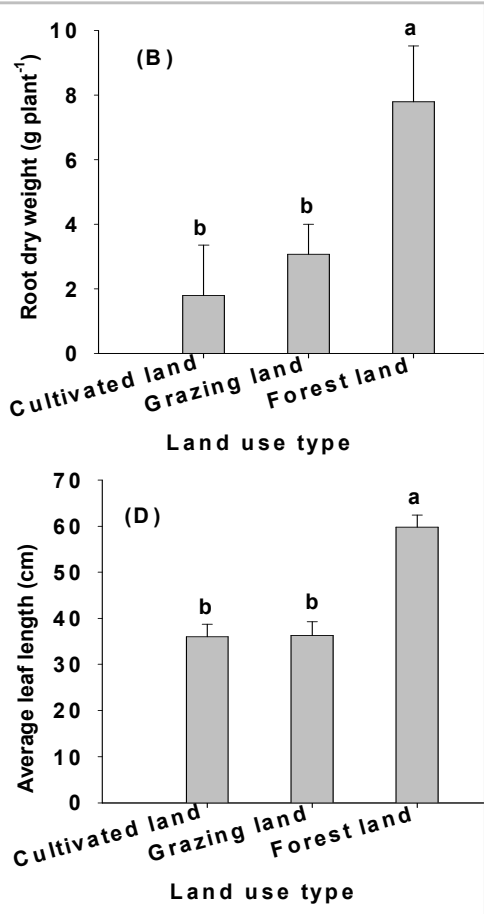

Land use type

Figure 5: Shoot weight $(A)$ root weight $(B)$ plant height $(C)$ average leaf length and root: shoot ratio of maize plant as influenced by soil taken from different land use types (Bars followed by the same letter are not significantly different from each other at probability level of $\alpha=0.05$ according to Tukey test)

Shoot weights of maize plant were significantly influenced by the different land use types $(p<0.01)$. The shoot dry weight $(\mathrm{g})$ of plants grown in soils taken from the three land use types were $3.25,9.15$ and 15.59 (Figure $5 \mathrm{~A}$ ) and shoot fresh weight $(\mathrm{g})$ were $16.75,31.1$ and 55.96 (data not presented) for cultivated, grazing and cultivated lands, respectively. Results showed that fresh and dry weights of the shoots of maize plant grown in soil taken from forestland were significantly higher than the fresh and dry weights of shoots of plants grown in soils taken from both grazing and cultivated lands. The shoot fresh and dry weights of plants grown in soils from grazing and cultivated lands did not, however, significantly different from each other. The lower shoot weight of maize plant grown in soil of cultivated and grazing lands can be ascribed to the lower nutrients content in soils of both cultivated and grazing lands. Plants suffering from nitrogen and phosphorus deficiency for instance show reduced shoot growth and become stunted in growth due to reduced growth rate.

Root dry and fresh weights of maize plant grown on different soil types were also influenced by the land use types $(p<0.01,0.001)$. The root dry weight $(\mathrm{g})$ of plants grown in soils of the three land use types were 1.79, 3.07 and 7.79 and root fresh weight were 8.68, 20.55 and $36.78 \mathrm{~g}$ for cultivated, grazing and cultivated lands, respectively. Data showed that the dry and fresh weights of root of maize plants grown in soil taken from forestland were significantly higher than the root dry and fresh weights of plant grown in soil of both grazing and cultivated lands. But root dry and fresh weights of plants grown in soils taken from cultivated and grazing land were at par. 


\section{Fedhasa Benti and Tesfaye Balemi}

The lower root dry and fresh weights of maize plants grown in soil from cultivated land might be due to deficiency nutrients that promote root growth as well due to oxygen limitation (related to soil compaction) that disfavored root growth since according to Drew and Goss (1973) both low oxygen availability and sub-optimal nutrient concentration in the soil generally reduces normal root development. However, under nutrient stress reduction in shoot growth is much higher than the reduction in root growth (Fredeen et al., 1989). In agreement with the present result Mohr (1978) also observed positive relationship between root growth and air space volume of the soil. He suggested that lower air space volume, which depends on soil bulk density, limits root growth.

The root: shoot ratio of the plant were significantly affected by different land use types $(p<0.001)$. The root: shoot ratio were, $0.55,0.39$, and 0.37 for cultivated, grazing and forest lands, respectively. The root: shoot ratio of maize plant grown in soil obtained from the cultivated land was significantly higher than that of the other land use types. This was related to the lower available plant nutrient content of soil from cultivated land compared to the other land use types since increased root: shoot ratio was one of the plant adaptation mechanisms to less mobile nutrient stress (Schenk and Barber, 1979). Due to severely reduced leaf growth under nutrient stress, leaf will have less demand for photo assimilates consequently causing translocation of photosynthates to the root (Cakmak et al., 1994) for better root growth. Preferential root growth thus helps the stressed plants to acquire more nutrients from the ambient environment in response to nutrient stress conditions.

\section{CONCLUSIONS}

The results obtained showed that soil taken from natural forestland had higher value of soil quality parameters such as: organic matter, total nitrogen and available phosphorus and potassium contents. Other soil quality parameters such as CEC, microbial population and micronutrient contents were also superior for forestland than for the other land use types. Crop growth parameters such as plant height, number of leaves per plant, shoot and root weights were all significantly higher for plant grown in soils taken from forestland than from the other land use types. The results clearly demonstrated that the different land use types had significant effects on soil quality and productivity suggesting that a change from forestland to the other land use types aggravated soil degradation, thereby resulting in soil fertility and productivity decline and hence in reducing crop productivity

\section{Conflict of Interest}

Authors declared no conflict of interest.

\section{Acknowledgement}

The first author would like to acknowledge the staff members of Oromia Development Association for facilitating the financial support without which this study could not be carried out as part of his MSc work. He also equally acknowledges the support made by West Shoa Zone Administration and ODA Executive Committee Chair person, Mr. Debebe Bayuu for allowing to pursue his higher studies. The first author also likes to thank the laboratory technicians working at Holeta Research Center
Sci. Technol. Arts Res. J., July-Sep 2015, 4(3): 83-92

for the assistance rendered in laboratory analysis of the soil samples.

\section{REFERENCES}

Adejuwon, J.O., Ekanade, O. (1988). A comparison of soil properties under different land use types in a part of the Nigerian cocoa belt. Catena 15: 319-331.

Aghasi , B., Jalalian, A. and Honarjoo, N. (2011). Decline in soil quality as a result of land use change in Ghareh Aghaj watershed of Semirom, Isfahan, Iran. African Journal of Agricultural Research 6(4): 992-997

Amede, T. (2003). Opportunities and Challenges in Reversing Land Degradation. The Regional Experience. In: Amede, T. (ed). Natural Resource Degradation and Environmental Concern in the Amhara National Regional State: Impact on Food Security. Ethiopian Soil Science pp 173-183.

Arshad, M.A., Lowery, B. and Grossman, B. (1996). Physical Tests for Monitoring Soil Quality. In: J.W. Doran, A.J. Jones (editors). Methods for assessing soil quality. Madison, WI. P 123-141.

Ayanaba, A., Tuckwell, S.B. and Jenkinson, D.S. (1976). The effects of clearing and cropping on the organic reserves and biomass of tropical forest soils. Soil Biology \& Biochemistry 8: 519-525.

Ayele, B. (2005). Land Degradation Assessment and Evaluation of Current Land uses and Soil Conservation Structures at Upper Chena Catchment, South Gondar, Ethiopia. MSc., Thesis, Addis Ababa University. Addis Ababa, Ethiopia, 82p.

Ayoubi, S. and Khormali, F., Sahrawat K.L., Rodrigues de Lima, A.C. (2011) Assessing Land Use Change on Soil Quality Indicators a Loessial Soil in Golestan Province, Iran. Journal of Agricultural Science and Technology 13: 727-742.

Barber, R. (1984). An assessment of the dominant soil degradation processes in Battlefield Park Mission Statement Plaque. Fort Harrison Headquarters. Richmond, Battlefield Park VA. Official Map and Guide.

Barton, L.L and Abadia, J. (2007). Iron Nutrition in Plant and Rhizosphere Microorganisms. Springer The Netherlands.

Bremner, J.M. and Mulvaney, C.S. (1982). Nitrogen-total. In: A. L. Page, et al. (Eds.), Methods of soil analysis. Part 2.

Cakmak, I., Hengeler, C. and Marschner, H. (1994). Partitioning of shoot and root dry matter and carbohydrates in bean plants suffering from phosphorus, potassium and magnesium deficiency. Journal of Experimental Botany 45: 1245-1250.

Charman, P.E.V. and Murphy, B.W. (Eds.) (2000). Soils: Their properties and Management. Oxford University Press, Melbourne, Australia

Collins, H.P., Blevins, R.L., Bundy, L.G., Christenson, D.R., Dick, W.A. Huggins, D.R. and Paul, E.A. (1999). Soil carbon dynamics in corn-based agro ecosystems: results from carbon-13 natural abundance. Soil Science Society of America Journal 63(3): 584-591.

Coppock, L. (1989). The arid and semi arid lowlands of Ethiopia: environments, Pastoral economies and issues in natural resources sustainability. In: Institute of Agricultural Research. Proceedings of the first natural resources conservation conference. Addis Ababa, Ethiopia.

Cotter, D.J. and Mishra, U.N. (1968). The Role of Organic Matter in Soil Manganese Equilibrium. Plant and Soil 3: 438-448. 
Fedhasa Benti and Tesfaye Balemi

Donovan, W.G. and Casey, F. (1998). Soil fertility Management in Sub-Saharan Africa. World Bank, Washington DC.

Doran, J.W. and Jones, A.J. (1996). Methods for Assessing Soil Quality. Spec. Publ. \# 49, SSSA, Madison, WI.

Doran, J. W., Sarrantonio, M. and M. A. Liebig (1996). Soil Health and Sustainability. p. 1-54 In D. L. Sparks (ed.), Advances in Agronomy, vol. 56 Academic Press, San Diego, CA.

Drew, M.C. and Goss, M.J. (1973). Effects of soil physical factors on root growth. Chem. and Ind. No. 14,679-684.

Eshetu. T. (2010). Assessment of Causes and Extent of Soil Degradation in Teltellee catchment. Msc. Thesis, Department of biology, Ambo university.

FAO (2004).Carbon sequestration in dry land soils, world soil resources reports No. 102. Food and Agricultural Organization, Rome, Italy.

FAO. (1999). Production year book. Vol.53

FAO. (2006). Scaling soil nutrient balances. Fertilizer and plant nutrition bulletin. 15. Rome. Production. Soil Bulletin, 80. Rome

Fredeen. A.L., Rao, I.M. and Terry, N. (1989). Influence of phosphorus nutrition on growth and carbon partitioning of Glycine max. Plant Phyiology 9: 225-230.

Islam, K.R. and Weil, R.R. (2000). Land use effects on soil quality in a tropical forest ecosystem of Bangladesh. Agriculture, Ecosystems and Environment 79(1): 9-16.

Jackson, M.L. (1973). Soil chemical analysis. New Delhi: Prentice-Hall.

Lal, R. (1986). Soil surface management in the tropics for intensive land use and high and sustained productivity. In: B. A. Stewart (ed), Advances in Soil Science.Vol.5. Springer- Verlag. New York.

Lal, R. (1987). Tropical ecology and physical edaphology. A wiley-interscience publication. pp.732.

Lal, R. (1994). Methods and guidelines for assessing sustainable use of soil and water resources in the tropics. Soil management support services technical monograph No. 21. pp 1- 78.

Lindsay, W. L., and Norvell, W. A. (1978). Development of a DTPA soil test for zinc, iron, manganese and copper. Soil Science Society America Journal 42: 421-428.

Lumbanraja, J., syam, T., Nishide H., Mahi, A.K., Utom, M., Sarno and Kimura. M. (1998). Deterioration of soil fertility by land use changes in South Sumatra, Indonesia: from 1970 to 1990. In hydrogical process 12, $2003-2013$. John Wiley and Sons Ltd.

Mengel, K. and Kirkby, E.A. (2001). Principles of plant nutrition. $5^{\text {th }}$ edition. Kluwer Academic Publisher, The Netherlands.

Mohr, H.D.(1978). Soil penetrations by roots in relation to important soil characteristics. Kali- Breife (Buntehof) 1(2): 103-113.

Mudimu, G. (1998). Population growth pressure and environmental degradation in Zimbabwe's communal lands: trends and implications for common property resource management. In: Harare (Zimbabwe). University of Zimbabwe.
Sci. Technol. Arts Res. J., July-Sep 2015, 4(3): 83-92

Mulumba, L.N. (2004). Land Use Effects on Soil Quality and Productivity in the Lake Victoria Basin of Uganda. Ph D thesis, The Ohio State University, USA.

Myers, N. (1991). Tropical forests: Present status and future outlook. Climate Change 19: 3-32

Nyle, C.B. and Ray, R.W. (2002). Nature and Properties of Soils. $13^{\text {th }}$ ed. University of Maryland at College park.

Olsen, S. R., Cole, C. V.,Watanable, F. S., and Dean, L. A. (1954). Estimation of available phosphorus in soils by extraction with sodium bicarbonate. USDA Circular 9398: 1-19.

Omotayo, O.E. and Chukwuka, K.S. (2009). Soil Fertility restoration techniques in Sub-Saharan Africa using Organic Resources. African Journal of Agricultural Research 4(3): 144-150.

Paul, E.A. and Clark, F.E. (1996) Soil Microbiology and Biochemistry, London: Academic Press.

Robert, M. (2001). Soil carbon sequestration for improved land management, World Soil Resource Report No. 90, FAO, Rome, Italy.

Rutberg, R. Schimel, D.S. Hajdas, I. and Broecker, W.S. (1996). The effect of tillage on soil organic matter using ${ }^{14} \mathrm{C}$ : a case study. Radiocarbon 38(2): 209-217.

Sachs, D. P. (1999). Edaphos: Dynamic of the natural soil system. pp. 152-153.

Schenk, M.K. and Barber, S.A. (1979): Root characteristics of corn genotypesas related to P uptake. Agronomy Journal 71: 921-924.

Schnitzer ,M. and Skinner, S.I.M. (1967). Organo metallic intereaction in soil. Stability constant of $\mathrm{Pb}-2, \mathrm{Ni}-2, \mathrm{Mn}$ 2,Co-2,Ca-2, and Md-2 fulvic acid complex. Soil Sci 103 , 247-252.

Silver, W.L. (1994). Is nutrient availability related to plant nutrient use in humid tropical forests. Oecologia 98(3-4): 336-343

Steenwerth K.L., Jackson, L.E., Calderon, F.J., Stromberg, M.R. and Scow K.M.(2002). Soil community composition and land use history in cultivated and grassland ecosystems of coastal California. Soil Biology \& Biochemistry 34(11):1599-1611.

Troeh, F.R. and Thompson, L.M. (1993). Soils and Soil Fertility. 5th ed. Oxford University Press. New York, NY. USDA. (1989). The Second RCA Appraisal

Veihmeyer, F.J. and Hendrickson, A.H. (1948). Soil density and root penetration. Soil Science 65: 487-493.

Walkley, A. J., and Black, C. A. (1934). An estimation of the Degtjareff method for determining soil organic matter and a proposed modification of the chromic acid titration method. Soil Science 37: 29-38.

Wild, A. (1993). Soils and the environment: An introduction. Cambridge University, pp 40-85.

Wolde, M. and Edzo, V. (2005). Impacts of Land Use Changes on Soil Nutrients and Erosion in Tigray, Ethiopia. Proceedings on International Agricultural Research for Development. October 11-13, 2005, Stuttgart-Hohenheim.

Zhang, C., Xue, S., Liu, G.B. and Song, Z.L. (2011). A comparison of Soil qualities of different revegetation types in the loess plateau. Plant and Soil 347:163-178. 